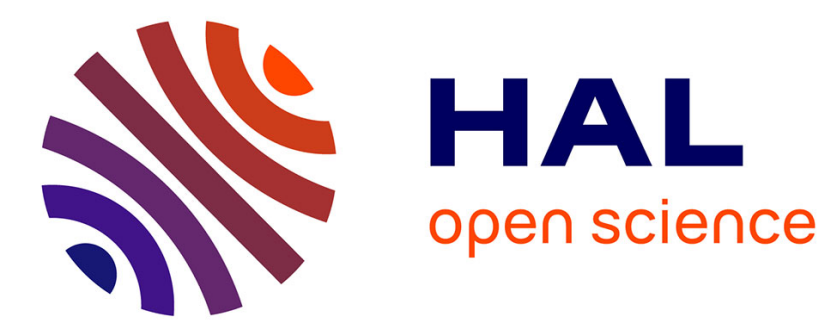

\title{
Plo Alastrué, Ramón and Carmen Pérez-Llantada: English as a scientific and research language \\ Shirley Carter-Thomas
}

\section{To cite this version:}

Shirley Carter-Thomas. Plo Alastrué, Ramón and Carmen Pérez-Llantada: English as a scientific and research language. Journal of English as a Lingua Franca, 2016, 5 (2), pp.377-382. 10.1515/jelf2016-0027 . halshs-01465147

\section{HAL Id: halshs-01465147 https://shs.hal.science/halshs-01465147}

Submitted on 15 Feb 2017

HAL is a multi-disciplinary open access archive for the deposit and dissemination of scientific research documents, whether they are published or not. The documents may come from teaching and research institutions in France or abroad, or from public or private research centers.
L'archive ouverte pluridisciplinaire HAL, est destinée au dépôt et à la diffusion de documents scientifiques de niveau recherche, publiés ou non, émanant des établissements d'enseignement et de recherche français ou étrangers, des laboratoires publics ou privés. 
Ramón Plo Alastrué, Carmen Pérez-Llantada (Eds)

English as a Scientific and Research Language (Debates and Discourses. English in Europe, Volume 2)

Publisher: Walter de Gruyter, 2015. 366 pp.

ISBN 978-1-61451-749-8

JELF book No.: 16-8

The use of English as a scientific and research language is today a subject of lively debate. The lingua franca role that English has assumed in many domains has given rise to numerous social, linguistic and geopolitical questions about this dominance over national languages. The present volume originated in the Zaragoza conference of December 2013 which was part of the larger English in Europe: Opportunity or threat? Project (2012-2014) ${ }^{1}$. One of the common goals of the chapters selected for this volume was to focus on the role of English in research settings in Europe specifically, and to identify trends and challenges related to the local geographic contexts in question. As underlined by Ramón Plo Alastrué in the introduction, contributions seek to "to identify both shared and divergent trends and challenges and contextualize scientific English usage across the local specificities of various geographic locations in Europe." The range of research settings in the book covers Northern, Central and Southern European countries, including Portugal, Spain, Germany, Italy, Czech Republic, Germany, Sweden, Romania, Croatia and Poland.

The book contains fifteen main chapters and a general introduction and is divided into three thematic parts. The first chapters are devoted to what is termed the "socio-cultural scenario", and raises several problematic geolinguistic issues related to publishing and knowledge dissemination by English L2 speakers. The second section, the "discourse community scenario", focuses more on language issues, investigating various cross-cultural variations that exist between English and certain other European languages as well as considering the effects of "English-only" publishing practices on researchers with different L2 backgrounds. The final section on the "language-policy scenario" mainly discusses academics" own perceptions and attitudes towards English as a lingua franca.

The chapters in Part 1 provide a strong start to the book. In particular, Karen Bennett's contribution, "Towards an epistemological monoculture: Mechanisms of epistemicide in European research publications", is extremely thought-provoking. Illustrating her arguments with several case studies of Portuguese academics' writings in English, Bennett shows how

\footnotetext{
${ }^{1}$ The project funded by the Leverhume Trust ran from January 2012-October 2014. http://englishineurope.group.shef.ac.uk/
} 
the various translations, revisions and editing processes the papers are subjected to, as well as other non-discursive mechanisms that put pressure on authors, can lead to the effective elimination of alternative knowledges and ways of writing, in this case of academic Portuguese. Bennett criticises those involved in mainstream EAP (English for Academic Purposes) who uncritically espouse the empirical (Anglo-Saxon) paradigm of research writing. She advocates more awareness-raising among linguists, teaching professionals and students in order to generate discussion about the epistemological underpinnings of different linguistic cultures, particularly by comparing ELF and the national language concerned. The chapter by Ruth Breeze entitled "Citing outside the community? An investigation of the language of bibliography in top journals" also raises the issue of information and identity loss due to Anglo-American academic dominance. Breeze's focus however is on citation practices. Using both a quantitative analysis - based on the analysis of ten journals in the social sciences - and semi-structured interviews with a selection of authors working in Spanish universities, Breeze seeks to analyse the extent to which scholars from countries outside the "inner circle" include references to work in languages other than English, and to propose explanations for their citing behaviour. The results of the quantitative study very much confirm the previous findings of Hewings, Lillis and Vladimirou (2010) that nonAnglophone academics rarely cite papers in languages other than English, even when papers are written by colleagues in the same shared native language. In Breeze's study only $0.81 \%$ of the sources referred to were in a language other than English. The interviews reveal a considerable amount of self-censorship, with authors fearing that they might compromise their chances of acceptance in English language journals if they cited publications in other languages, and choosing on the contrary to cite almost exclusively English publications to present themselves as members of the international academic community.

The following chapter, "Resources for publishing in English: Strategies, peers and techniques” by Claus Gnutzmann, Jenny Jakisch and Frank Rabe, also concerns publishing. Drawing on the interview corpus of the PEPG (Publish in English or Perish in German) project, the authors investigate the strategies used by German-speaking researchers when preparing research articles in English. The strategies and resources mentioned include using dictionaries and Google, reusing formulaic language from existing publications, and making use of proof-reading help from native and non-native speaking peers. The results suggest that collective writing and revision strategies may be more important than individual language competence in publishing success. The last chapter in Part 1 by Marina Bondi, 
"Language policy in web-mediated scientific knowledge dissemination: A case study of risk communication across genres and languages", is written from rather a different perspective as it is set in the political context of a European agency, the EFSA (European Food Safety Authority). The author proposes a case study of the section of the EFSA website devoted to genetically modified organisms, analysing its structural characteristics and the various language choices. Whereas English is the dominant language in the more technical sections, translations into other languages are used in the news and opinions sections that are more likely to interest the general public. Although interesting as a stand-alone article, this chapter introduces some rather different concerns and its position, immediately after three chapters about writing in university contexts, is a little disconcerting.

Part 2 of the book moves on to discuss various issues related to cross-cultural variation in academic texts and the first three chapters focus on the use of specific linguistic phenomena by researchers from different European backgrounds. Renata Povolná's chapter is entitled "Cross-cultural variation in the use of conjuncts by Czech and native speakers of English" and aims to discover whether there is cross-cultural variation in the use of these textorganizing devices in English research articles written by these groups of authors. Sonia Olivier's chapter, "Spanish authors dealing with hedging or the challenges of scholarly publication in English L2", examines the use of hedges in Spanish and English research writing. The chapter by Josef Schmied, “Academic writing in English in comparison: Degree adverbs, connecting adverbials and contrastive/concessive markers in the ChemCorpus and comparable data-bases", considers how students from different writing cultures use a range of markers and linkers. Although all three articles focus on linguistics issues, Povolná and Schmied also address wider, more controversial questions. Povolná for example queries whether it is justified to impose the linguistic standards and style conventions typical of the Anglo-American discourse community on international academics. Schmied for his part argues forcefully that "internationalisation does not have to mean globalisation and Englishization" (p.181) and makes the case for a common European lingua franca for academic writing. The fourth chapter by Olga Dontcheva-Navratilova is entitled "Crosscultural variation in citation practices: A comparative analysis of citations in Czech Englishmedium and international English-medium journals". The author's conclusions here suggest that Czech and Anglophone linguists vary in the way they use the rhetorical potential of citations, with the Czech authors in the sample striving to represent themselves as members not only of the local community but also of the global academic community. Referring as it 
does to certain geo-linguistic questions involved in citation practices, this chapter would arguably have been better placed following the study of Ruth Breeze in Part 1 . The final chapter in Part 2, "Peer reviewers' recommendations for language improvement in research writing", is by Ana Bocanegra-Valle. Her analysis is based on the examination of 258 peer review reports produced for the multilingual journal Ibérica. Reviewers' comments on language quality are correlated with the acceptance or rejection outcome, the author's profile (Anglophone or non-Anglophone), and the type of language infelicities noted. One of the interesting conclusions she come to is the fact that language problems are not exclusive to non-Anglophone writers and that content-related factors ultimately outweigh poor use of English in the final decision to accept a paper or not. This concurs with Hewing's (2006) finding that non-native English speakers are not necessarily disadvantaged in relation to native English speakers because of their L1. Bocanegra-Valle's also notes the constructive nature of many reviewers' language comments and the inclusion of specific alternatives for rephrasing, which strengthen in her view 'the reviewer's role as a guider, mentor and ally (not only gatekeeper) in the submission-revision-publication process" (p. 227).

The emphasis in the chapters composing Part 3 of the book is on researchers' own views and attitudes towards the use of English in academic settings. The first contribution by Jennifer Schluer is entitled "English as a lingua franca in linguistics? A case study of German linguists' language use in publications". Schluer's study is based on the analysis of interviews conducted with 16 linguists in the field of English, German and Romance linguistics at a German university. Her results suggest three main factors affecting researchers' choice of language: the target audience, the object of their research and the actual linguistic level of the individual researcher. Schluer claims that for a scholar in Romance and German linguistics these three factors often come into conflict, pulling in opposing directions. Maria Kuteeva's contribution is entitled "Academic English as 'nobody's land"”. This chapter provides an overview of recent research carried out on Swedish university academics and provides some interesting insights into their research and publication practices. Kuteeva insists on the general acceptance of English in Swedish universities as a "nobody's land". Although some informants reported difficulties when writing in the humanities, most overall do not feel disadvantaged by their non-native English status. In her conclusion, Kuteeva predicts that although English will often be the main language used in multilingual academic settings, Swedish and other languages will continue to be used for outreach and for more local research purposes, challenging the claims of Englishization and linguistic imperialism made by 
Phillipson (1992). The third chapter in this section, by Laura Mihaela Muresan and Mariana Nicolae, focuses on the Romanian context and is entitled: "Addressing the challenge of publishing internationally in a non-Anglophone academic context. Romania - a case in point". Although until recently there was a strong Francophone academic tradition, the authors note that internationalisation means that ELF is now a reality in most Romanian universities. In a qualitative study involving editors and researchers primarily in the economic and business sectors, the authors of the chapter set out to identify the principal challenges for scholars publishing in English-medium Romanian journals. Branka Drljača Margić and Tea Žeželić, in "The Implementation of English-medium instruction in Croatian higher education: Attitudes, expectations and concerns", focus on the issue of English medium instruction (EMI). The Croatian students from the University of Rijeka who responded to questionnaires appeared reluctant to accept the idea of EMI. The authors' findings though also revealed several paradoxes, with respondents for example expecting EMI, if implemented, to improve their English level and prepare them better for the job market. The last chapter in Part 3 is set in the Polish university context. Joanna Lewińska's “Teaching English as a Lingua Franca in a multilingual academic environment: The evaluation of native and non-native teachers of English by Polish University students" focuses on philology students' attitudes towards native and non-native teachers of English. Lewińska underlines the need for English university teachers to take the ELF phenomenon into account and to demonstrate flexibility by adapting their ways of teaching to suit the linguistic and cultural expectations of learners

Overall, this volume is an excellent contribution to a growing body of studies on academic and scientific ELF. One of the richest aspects of the book is undoubtedly its presentation of current research as well as the range of academic settings covered. Eleven European countries are examined, providing a wealth of data on these often very different academic contexts and traditions. (One other European country that could have usefully been included in the survey is arguably France, where resistance to English dominance in publication can be relatively strong, particularly in the humanities and social sciences). The book is on the whole readerfriendly. Care has been taken to define terms and chapters are preceded by fairly extensive literature reviews, which means that even readers who are not experts in ELF studies will be able to appreciate the issues raised. Although the chapters are regrouped in the three broad sections outlined, contributions may also be read as self-contained articles and each chapter 
contains a separate bibliography. The drawback of this for the reader who undertakes to read the whole volume is a certain degree of inevitable redundancy, and also a slight feeling of inadequacy faced with the daunting task of sorting and hierarchizing the mass of information about the different settings presented. Fortunately, this problem is partially overcome by Carmen Pérez-Llantada's concluding chapter, “Teasing out the tensions between English monolingualism vs. plurilingualism in European academic and research settings", in which a certain number of strands are pulled together. Among the challenges for the future identified in this chapter, Pérez-Llantada returns to the thorny question of providing support for academics who need to disseminate their research in English. Whilst recognising that instructional support and language consultancy are often the best means to empower ELF users as professionals, she echoes Karen Bennett's concerns about better problematizing academic English use by teaching it contrastively with reference to students' own languages. An emphasis on biculturality and a command of more than one communicative style, as proposed by Clyne (1996), remain invaluable approaches, in the view of Pérez-Llantada

\section{References}

Clyne, Michael. 1996. Inter-cultural communication at work. Cultural Values in Discourse. Cambridge: Cambridge University Press.

Hewings, Martin. 2006. English language standards in academic articles: attitudes of peer reviewers. Revista Canaria de Estudios Ingleses 53, 47-62.

Hewings, Ann, Theresa Lillis and Dimitra Vladimirou. 2010. Who's citing whose writings? A corpus based study of citations as interpersonal resource in English medium national and English medium international journals. Journal of English for Academic Purposes 9. 102115 .

Phillipson, Robert. 1992. Linguistic imperialism. Oxford: Oxford University Press.

Shirley Carter-Thomas

Insitut Mines-Télecom/TEM, Evry, France

Shirley.Thomas@telecom-em.eu 